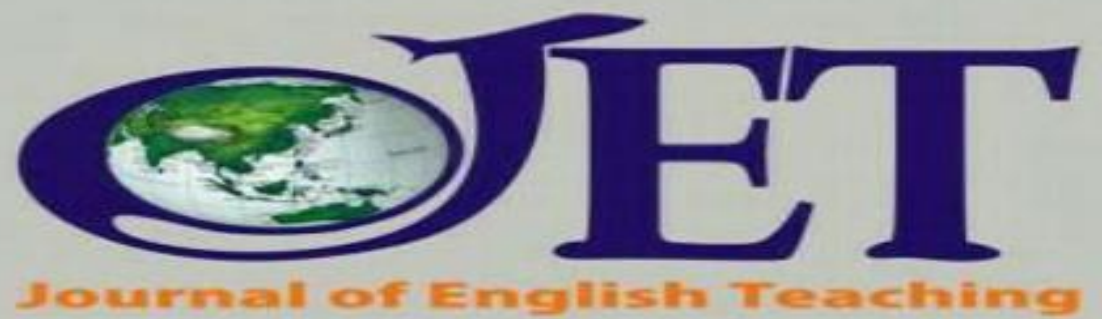

ISSN 20809628

a triannual publication on the study of English L anguage Teaching

Volume 3 Number 1, February 2017

\title{
Developing Students' Vocabulary through Watching English Cartoon Films at SMP BHAKTI
}

\author{
Christopley \\ ravel.mapaloto7@gmail.com \\ SMTK Bukit Inspirasi Lumbi-Lumbia
}

\begin{abstract}
This was a research report on developing students' vocabulary through watching English cartoon films. The objectives of this research were to develop students' vocabulary and students' responses on learning vocabulary through watching English cartoon film at SMP BHAKTI, Jakarta. This research used classroom action research (CAR) method in which the students consisted of 23 eighth graders of SMP BHAKTI, Jakarta and comprised 15 males and 8 females. To collect the data the researcher used test and nontest techniques. The test technique was realized in pre-test and post-test; while the nontest one was in questionnaire, observation sheet, and diary notes. Based on the test analysis results, it was found that the mean score of the pretest, post-test in Cycle 1 and 2 were 60.73 points, 0.86 points, and 90.00 points respectively. The gain between the posttest and pre-test scores in Cycle 1 was $33.14 \%$ and the gain between the post-test in Cycle 1 and post-test scores in Cycle 2 was $11.30 \%$. The gain between pre-test and post-test scores in Cycle 2 was $48.69 \%$. Therefore, it can be concluded that watching English cartoon films could develop the eighth graders' vocabulary of SMP BHAKTI, Jakarta. Besides, based on the questionnaire, observation sheet, and diary notes analysis results, it was revealed that students agreed that watching English cartoon films was a good strategy to develop their vocabulary. The conclusion is that watching English cartoon films can develop students' vocabulary.
\end{abstract}

Keywords: English cartoon films, vocabulary, action research

\section{Introduction}

Vocabulary is one of the important language components. It is even a basic material of a language and the body of the word that makes up a language. Kridalaksana (as cited in Muttahidah, 2011) stated that vocabulary is a component of a language that maintains 
all of information about definitions and using words in language. Similarly, Hatch and Brown (1995) describes vocabulary as a list or set words for a particular language or a list or set of word that individual speaker of language might use. In addition, Morris (1979) stated that vocabulary is an alphabetical list of words, often phrases, usually arranged alphabetically and defined or translated; a lexicon or glossary. Thus, people who have limited English vocabulary will encounter trouble in communication in that language. Consequently, vocabulary learning becomes an important aspect in learning a language especially foreign language, such as English (Jumariati (2010). By having acquired adequate vocabulary students are enabled to express ideas, feelings, and opinions through interaction and communication. However, vocabulary learning is not inevitable from other language sub skills learning, such as pronunciation and spelling, or the language skill achievement: listening, speaking, reading, and writing.

Based on the researcher's observation and information collected from the eighth graders English teachers at SMP BHAKTI, Jakarta, the main problem the eighth graders encountered was the inadequacy of vocabulary mastery. Almost $60 \%$ of the students found it difficult to differentiate word classes among verbs, adjective, and nouns, for instances. Thirty percent of them felt confused of how to find the antonyms of the words; and $75 \%$ was lacked of understanding of word definitions. Besides, the eighth graders were informed so hard to focus on English subject learning. Such conditions were also evidenced through the pre-test scores of vocabulary. Since, the mean scores of the pretest was 60.73 , it is obviously stated that the students' scores was still under the minimum achievement criteria $(\geq 66)$. Due to the problems above, in this research the researcher focused the study on the vocabulary learning only, especially in word classes (noun, verb and adjective), antonym and word definitions. Believed that language is not biologically inherited but it is mastered through some efforts (Dakhi \& Zagoto, 2016), the researcher was inspired to conduct an action research using English cartoon films as a technique to develop the students' vocabulary. Pardede (2012) posited that action research can give insight to teachers about their own beliefs, mood and perceptions of students, and the weaknesses to improve and solve.

Cartoon film is a film produced by photographing a series of gradually changing drawings, etc, which provides the illusion of movement when the series are rapidly projected. Poulson (as cited in Mukti, 2012) remarks that, basically, a cartoon is a form 
of media where, using animation, characters are shown in simplified features although it still requires an ability to recognize. In addition, Woodford and Walter (2004) underlines that cartoon is: (a) a film made using characters that are drawn and not real(for instance, Mickey Mouse and other famous cartoon characters); (b) a funny drawing, especially in a newspaper or magazine. The description of cartoon implies that using cartoon films in a classroom would likely make the students entertained, focused, active, and acquire a lot of new vocabularies. Besides, it may help the teacher create contexts through which language learning is useful and meaningful.

Realizing the role of watching English cartoon films to develop students' vocabulary, the researcher would like to investigate whether students' vocabulary could develop by applying English cartoon film watching as a technique and to see how watching English cartoon films develop the students' vocabulary. In order to meet the goal, the researcher implemented the technique in CAR. Consequently, the researcher addressed the following two research problems: (1) "Does watching English cartoon films develop the students' vocabulary?" (2) "How does watching English cartoon films develop the students' vocabulary?" It is highly expected that this action research will shed light on the way and the benefits of using cartoon film in eighth grade at SMP BHAKTI.

\section{Methodology}

This study used an action research design, i.e. a principled way of observing one's teaching, reflecting upon it, and trying to analyze its weaknesses and increase its strengths. ... through which educators can help themselves and their students overcome the specific problems they encounter in the learning and teaching process" (Pardede, 2016, p.143). It was was conducted at SMP BHAKTI,Jl. Perindustrian No. 7 Cawang Jakarta Timur 13650, in 2015/2016 Academic Year. This research was conducted approximately within two months in two meetings per week and 90 minutes per session. The students participating in this research were the eighth graders of SMP BHAKTI as the subjects, comprising 23 students (15 male and eight female students). The data were collected using test and non-test techniques. The test instrument was taken from the students' pre-test, post-test in Cycle 1 and post-test in Cycle 2scores. The non-test was realized using observation sheet, dairy notes, and questionnaire. The data then were analyzed quantitatively and qualitatively. The quantitative data were collected and 
analyzed by computing the scores of pre-test, post-test in Cycle 1 and of post-test in Cycle 2. The qualitative data were obtained and analyzed using Likert scale (for questionnaire), descriptive technique (for observation sheet and dairy notes)in order to know the students' opinions of watching English carton films in developing their vocabulary. As the basis of the development, the researcher used the minimum achievement criteria of English subject that is 66.00 at SMP BHAKTI, Jakarta.

\section{Result}

In common, the students' vocabulary mastery at SMP BHAKTI Jakarta was categorized low. This statement was based on the information that the majority of students got difficult when they were demanded to recognize the meaning of some words. The students

Table 1

Students' Pre-test Scores

\begin{tabular}{ccc}
\hline Scores & Frequency & Percentage (\%) \\
\hline $\mathbf{6 6 6 . 0 0}$ & 9 & 39.13 \\
$\leq \mathbf{6 6 . 0 0}$ & 14 & 60.87 \\
\hline Total & 23 & 100.00
\end{tabular}

Note: Criteria minimum achievement $=66.00$ points

admitted that they got difficult in remembering the words and they got bored of English sessions. The students' mastery of the vocabulary in the initial condition was as follows:

Table 1 above shows that 9 of 23 students (or 39.13\%) achieved the minimum achievement criteria. The rests $(60.87 \%)$ did not achieve the minimum achievement criteria. This finding was consistent with the information from the English teacher that

Table 2

Range of Students' Pre-test Scores

\begin{tabular}{cccc}
\hline Range of Score & Frequency & Percentage $(\%)$ & Category \\
\hline $75.10-100.00$ & 0 & 0.00 & Very Good \\
$58.40-75.00$ & 12 & 52.18 & Good \\
$41.70-58.30$ & 10 & 43.48 & Fair \\
$25.00-41.60$ & 1 & 4.34 & Poor \\
$0.00-24.90$ & 0 & 0.00 & Very Poor \\
\hline Total & 23 & 100.00 &
\end{tabular}


many students were lacked of English vocabulary. The consistency was strengthened by the range of the pre-test scores shown in Table 2.

Based on the analysis result of the pre-test, it was found that the mean score of the pretest was 60.73 points. It indicated that the minimum achievement criteria had not been met. There was only one subject (4.34\%) went to the poor category. Ten students $(43.48 \%)$ got 'Fair' category; and 12(52.18\%) got 'Good' category. Table 2 indicates that none achieved 'Very Good' category.

Cycle 1 was conducted in two treatments, beginning on Monday, April 18, 2016 for the first treatment, and Monday, April 25, 2016 for the second treatment. Post-test 1 was conducted on Monday, April 25, 2016. The implementation of Cycle 1 began with the planning process, and followed by the implementation of acting, observing and reflecting.

\section{Planning}

In this phase, the researcher analyzed the syllabus, prepared a topic to teach (the English cartoon film and exercises related to vocabulary). Then, the researcher designed the lesson plans and teaching instruments for post-test 1 . There were two treatments in the first Cycle.

\section{Action}

Cycle 1 was conducted in two treatments. In the first treatment, the students were divided in two groups. The first group contained11 students; and the second group contained 12 students. The division was done because the school did not have LCD facilities. After the researcher had divided the students in groups, the researcher asked every group to focus on ten verbs, nouns, and adjectives during watching the English cartoon films that was played by the researcher. When the film had completed, the researcher gave five to ten minutes to the students to choose three words and used them to make sentences as an exercise and wrote and submit them on a work sheet. After that, the researcher started teaching by taking verbs, adjectives, and nouns as the topics. Then, the researcher and the students discussed what they have done through the work they had submitted together. In the second treatment the researcher did the same way, but in this phase, the students only found 10 verbs and adjectives. Afterwards, the students were supposed to find the antonyms and definitions of the words they got during English 
cartoon film watching session. Finally, the researcher conducted the final test. This final test was regarded Post-test 1inCycle 1 and presented in Table 3

Table 3

Students' Post-test Scores in Cycle 1

\begin{tabular}{ccc}
\hline Scores & Frequency & Percentage $(\%)$ \\
\hline$\geq 66.00$ & 19 & 82.60 \\
$\leq 66.00$ & 4 & 17.40 \\
\hline Total & 23 & 100.00 \\
\hline
\end{tabular}

Note: Criteria minimum achievement $=66.00$ points

Table 3 shows that nineteen students or $82.60 \%$ of the students who scored according to criteria minimum achievement while four students or $17.40 \%$ of the students have not reached it. Furthermore, the details of Cycle 1 of the students' post-test 1 result as follows:

Table 4

Range of Students' Pre-test Scores in Cycle 1

\begin{tabular}{cccc}
\hline Range of score & Frequency & Percentage $(\%)$ & Category \\
$75.10-100.00$ & 14 & 60.87 & Very Good \\
$58.40-75.00$ & 8 & 34.79 & Good \\
$41.70-58.30$ & 1 & 4.34 & Fair \\
$25.00-41.60$ & 0 & 0.00 & Poor \\
$0.00-24.90$ & 0 & 0.00 & Very Poor \\
\hline Total & 23 & 100.00 &
\end{tabular}

The mean score in Post-test 1 was 80.86 points. Table 4 shows 14 students (or $60.87 \%$ ) got 'Very Good' category;8(or 34.79\%) got 'Good' category; one (or 4.34\%) got 'Fair' category. None of them got 'Poor' or 'Very Poor' category.

\section{Observing}

Based on the observation conducted by the researcher and an observer, some students were still found talking with the others during the learning process and others were found feeling bored during the film show. However, the rests were active in class during the film show. Such conditions occurred because the cartoon film did not attract. All the situations were taken into notes in researcher's diary notes. During the implementation of 
the treatments in the first Cycle, the researcher analyzed the observation sheet which was observed by the observer. Table 5 indicates the result of observation every treatments of Cycle 1.

\section{Table 5}

Observation AnalysisResult inCycle 1

\begin{tabular}{|c|c|c|c|c|c|c|}
\hline \multirow[t]{3}{*}{$\begin{array}{l}\mathrm{N} \\
\mathrm{o}\end{array}$} & \multicolumn{2}{|c|}{ Focus and Topics } & \multicolumn{2}{|c|}{$\begin{array}{c}\text { Meeting } \\
1 \\
\end{array}$} & \multicolumn{2}{|c|}{$\begin{array}{c}\text { Meeting } \\
2\end{array}$} \\
\hline & Teacher's activities & Students' activities & Yes & $\mathrm{N}$ & Yes & $\mathrm{N}$ \\
\hline & & & & o & & o \\
\hline 1 & Greeting the students & $\begin{array}{l}\text { Responding the teacher's } \\
\text { greeting }\end{array}$ & $\sqrt{ }$ & & $\sqrt{ }$ & \\
\hline 2 & Calling the students & Responding the teacher & $\sqrt{ }$ & & $\sqrt{ }$ & \\
\hline 3 & $\begin{array}{l}\text { Conveying the learning } \\
\text { objective }\end{array}$ & Responding the teacher & $\sqrt{ }$ & & $\sqrt{ }$ & \\
\hline 4 & Explaining the material & Hearing to the teacher & $\sqrt{ }$ & & $\sqrt{ }$ & \\
\hline 5 & $\begin{array}{l}\text { Asking the students to do the } \\
\text { exercises }\end{array}$ & Responding the teacher & $\sqrt{ }$ & & $\sqrt{ }$ & \\
\hline 6 & Playing the cartoon film & Watching the cartoon film & $\sqrt{ }$ & & $\sqrt{ }$ & \\
\hline 7 & Checking the students' work & Correcting their wrong answer & $\sqrt{ }$ & & $\sqrt{ }$ & \\
\hline 8 & $\begin{array}{l}\text { Asking what they don't } \\
\text { understand }\end{array}$ & $\begin{array}{l}\text { Telling what they don't } \\
\text { understand }\end{array}$ & $\sqrt{ }$ & & $\sqrt{ }$ & \\
\hline 9 & Answering students' questions & Hearing to the teacher & $\sqrt{ }$ & & $\sqrt{ }$ & \\
\hline 10 & & Became active & $\sqrt{ }$ & & & $\sqrt{ }$ \\
\hline 11 & & Interesting to the cartoon films & & $\sqrt{ }$ & & $\sqrt{ }$ \\
\hline 12 & Using time effectively & & & $\sqrt{ }$ & & $\sqrt{ }$ \\
\hline 13 & Using the cartoon film & & $\sqrt{ }$ & & $\sqrt{ }$ & \\
\hline 14 & $\begin{array}{l}\text { Using LCD, Whiteboard, } \\
\text { board marker }\end{array}$ & & & $\sqrt{ }$ & & $\sqrt{ }$ \\
\hline 15 & Giving clear instructions & & $\sqrt{ }$ & & $\sqrt{ }$ & \\
\hline & Tot & & 12 & 3 & 11 & 4 \\
\hline
\end{tabular}

As shown in Table 5, in the first meeting 12 studentsput a check $(\sqrt{ })$ in column "YES" and 3 in column "NO" by the observer concerned with the researcher's teaching performance. In the second meeting there were 11 checks in column "YES" and 4 in column "NO". In order to strengthen the data in Table 5, the researcher used the data put in the diary notes. Based on the diary notes, it was reported that the researcher and the students had implemented watching English cartoon film in learning vocabulary (see Table 6).

As shown in the table, it was concluded that the process of learning vocabulary through watching English cartoon film in Cycle 1 were responded variously by the students. Some actively responded that the learning process run well; and the others were found still not serious. 
Table 6

Description of Diary Notes in Cycle 1

1. Monday, It was the first meeting for the research between the researcher and the students. April In the same day, the researcher gave pre-test then did the first treatment in Cycle 18th, 1 but before gave the pre-test, the researcher informed the students what the 2016 researcher would do with them during next two months then told his undergraduate thesis' title. In the first treatment, the researcher divided the students into two groups for watching the cartoon film (the researcher's reason to divide the students in groups because there was no LCD). In this treatment the researcher played a cartoon film and asked them to find noun, verb and adjective during watching the English cartoon film and after watched the cartoon film, the researcher explained the definition about noun, verb and adjective. In teaching learning process, the researcher observed how the students' interest to watch the cartoon film and did the exercises and the researcher found some students not serious to watch the cartoon film and told with their friends. It was because the cartoon film played by the researcher was not interested and the time of teaching was in the afternoon.

2. Monday, The second meeting in Cycle 1, the researcher came to the class and informed April the students what topic was going to be learned on the day. Thereafter, the 25th, researcher divided the students into two groups again and played the next 2016 episode of the cartoon film in first treatment and asked the students found antonyms of the words that they got from the film and found the word definition of the word that they got in the cartoon film. After watched the cartoon film and did the exercises, the researcher explained the definition about antonyms, word definition and gave the examples. In this treatment, the researcher observed again the teaching learning process and about $80 \%$ of the students active to follow the teaching learning process while $20 \%$ of the students still told with their friends during the cartoon film played and did not pay attention to the explanation given.

\section{Reflecting}

After conducting watching English cartoon films in Cycle 1, some students were found still bored and conducted conversation with the others during the session. They felt hard to remember the vocabularies they had listened in the film. It was seen from the posttest scores (see Table 3).Four of the students could not reach the minimum achievement criteria. By the fact and observation noted, the researcher prepared to design a more interesting lesson plans for the next cycle.

As in the first Cycle, Cycle 2 was conducted in two treatments, performed on Monday, May 2, 2016. The learning process in Cycle 2 started ranging from planning, acting, observation to reflecting. 


\section{Planning}

Based on the reflection in Cycle 1, the researcher continued to Cycle 2 in order to create more creative and attracting learning process. In this phase, the researcher prepared some teaching materials, including the English cartoon film and some exercises related to vocabulary learning. In order to work on these activities, the researcher went through two treatments.

\section{Action}

In the first treatment, the researcher briefly informed the students had achieved in Cycle 1. The researcher expressed appreciation to those with high scores and motivated those with low scores. After that, the researcher suggested the students to be involved in two groups again but with different members from those in previous Cycle 1, expecting they got new knowledge from other members. After the group was formed, the researcher asked each group to focus on finding20nouns, adjectives, and verbs during watching the English cartoon films. When they had completely watched the film, the researcher spent five to ten minutes to the students to choose six of the words they had focused on. They were supposed to make sentences using the words as the exercises. After the students had done the exercises, the researcher asked them to submit their work. Then, the researcher explained the verbs, adjectives, and nouns before the class. After that the researcher and students discussed their works together. In the second treatment the researcher did the same way, but in this treatment, the students only found 20 verbs and adjectives. Afterwards, the students were required to find the antonyms and definition of the words they had got from the English cartoon film conversations. Finally, the researcher administered a final test for post-test 2 .

\section{Observing}

Based on the observation conducted by the researcher and the observer, all the students were found focused and not bored during the cartoon film show and the researcher's explanation of the materials. In this cycle, the researcher also wrote the activities happening during the phase in researcher's diary note. The results of post-test in Cycle 2 are presented in Table 7. 
Table 7

Students' Post-Test Scores in Cycle 2

\begin{tabular}{ccc}
\hline Scores & Frequency & Percentage (\%) \\
$\mathbf{2 6 6 . 0 0}$ & 22 & 95.66 \\
$\leq \mathbf{6 6 . 0 0}$ & 1 & 4.34 \\
\hline Total & 23 & 100.00 \\
\hline
\end{tabular}

Note: Criteria minimum achievement $=66.00$ points

Table 7 shows that 22 students (or 95.66\%) reached the minimum achievement criteria. There was only one student (or 4.34\%)did not. Based on the observation results, the students who did not reach the minimum achievement criteria was in fact experienced a psychiatric disorder that made herso hard to understand the materials taught. The detail of the students' posttest 2 scores was displayed as follows:

Table 8

Range of Students' Post-Test Scores in Cycle 2

\begin{tabular}{cccc}
\hline Range of score & Frequency & Percentage (\%) & Category \\
$\mathbf{7 5 . 1 0}-\mathbf{1 0 0 . 0 0}$ & 21 & 91.30 & Very Good \\
$\mathbf{5 8 . 4 0 - 7 5 . 0 0}$ & 2 & 8.70 & Good \\
$\mathbf{4 1 . 7 0}-\mathbf{5 8 . 3 0}$ & 0 & 0.00 & Fair \\
$\mathbf{2 5 . 0 0}-\mathbf{4 1 . 6 0}$ & 0 & 0.00 & Poor \\
$\mathbf{0 . 0 0}-\mathbf{2 4 . 9 0}$ & 0 & 0.00 & Very Poor \\
\hline Total & 23 & 100.00 & \\
\hline
\end{tabular}

In this cycle, the mean score of post-test 2 was 90.00 points. The students' vocabulary mastery improved in post-test 2 . In addition, of 23 students, 21 students (or $91.30 \%$ ) reached 'Very Good' category with a range score 75.10-100.00 and only two students (or $8.70 \%$ ) achieved 'Good' category. During the implementation of the treatments in Cycle 2, the researcher analyzed the observation sheet noted by the observer. Table 9 indicates the description of the observation in Cycle 2. 
Table 9

Description of Observation in Cycle 2

\begin{tabular}{|c|c|c|c|c|c|c|}
\hline \multirow[t]{3}{*}{ No } & \multicolumn{2}{|c|}{ Focus and Topics } & \multicolumn{2}{|c|}{$\begin{array}{c}\text { Meeting } \\
3\end{array}$} & \multicolumn{2}{|c|}{$\begin{array}{c}\text { Meeting } \\
4\end{array}$} \\
\hline & Teacher's activities & Students' activities & Yes & $\mathrm{N}$ & Yes & $\mathrm{N}$ \\
\hline & & & & o & & o \\
\hline 1 & Greeting the students & $\begin{array}{l}\text { Responding the teacher's } \\
\text { greeting }\end{array}$ & $\sqrt{ }$ & & $\sqrt{ }$ & \\
\hline 2 & Calling the students & Responding the teacher & $\sqrt{ }$ & & $\sqrt{ }$ & \\
\hline 3 & $\begin{array}{l}\text { Conveying the learning } \\
\text { objective }\end{array}$ & Responding the teacher & $\sqrt{ }$ & & $\sqrt{ }$ & \\
\hline 4 & Explaining the material & Hearing to the teacher & $\sqrt{ }$ & & $\sqrt{ }$ & \\
\hline 5 & $\begin{array}{l}\text { Asking the students to do the } \\
\text { exercises }\end{array}$ & Responding the teacher & $\sqrt{ }$ & & $\sqrt{ }$ & \\
\hline 6 & Playing the cartoon film & Watching the cartoon film & $\sqrt{ }$ & & $\sqrt{ }$ & \\
\hline 7 & Checking the students' work & Correcting their wrong answer & $\sqrt{ }$ & & $\sqrt{ }$ & \\
\hline 8 & $\begin{array}{l}\text { Asking what they don't } \\
\text { understand }\end{array}$ & $\begin{array}{l}\text { Telling what they don't } \\
\text { understand }\end{array}$ & $\sqrt{ }$ & & $\sqrt{ }$ & \\
\hline 9 & Answering students' questions & Hearing to the teacher & $\sqrt{ }$ & & $\sqrt{ }$ & \\
\hline 10 & & Became active & $\sqrt{ }$ & & $\sqrt{ }$ & \\
\hline 11 & & Interesting to the cartoon films & $\sqrt{ }$ & & $\sqrt{ }$ & \\
\hline 12 & Using time effectively & & $\sqrt{ }$ & & $\sqrt{ }$ & \\
\hline 13 & Using the cartoon film & & $\sqrt{ }$ & & $\sqrt{ }$ & \\
\hline 14 & $\begin{array}{l}\text { Using LCD, Whiteboard, } \\
\text { board marker }\end{array}$ & & & $\sqrt{ }$ & & $\sqrt{ }$ \\
\hline 15 & Giving clear instructions & & $\sqrt{ }$ & & $\sqrt{ }$ & \\
\hline & Total & & 14 & 1 & 14 & 1 \\
\hline
\end{tabular}

As shown in Table 9, in the first meeting there were 14 check $(\sqrt{ })$ symbols in column "YES" and 1 in column "NO" by the observer and shown to the researcher. In the second meeting 14 check symbols were in column "YES" and 1 in column "NO". To strengthen the improvement data in Cycle 2, the researcher used diary notes. Based on the data in the diary notes, it was reported that the researcher and the students had implemented watching English cartoon film in learning vocabulary well (see Table 10)

The description in the table implied that the process of vocabulary learning through watching English cartoon film in Cycle 2 ran well. In this cycle, the researcher found that all students were encouraged to focus on the materials taught during the learning process. 
Table 10

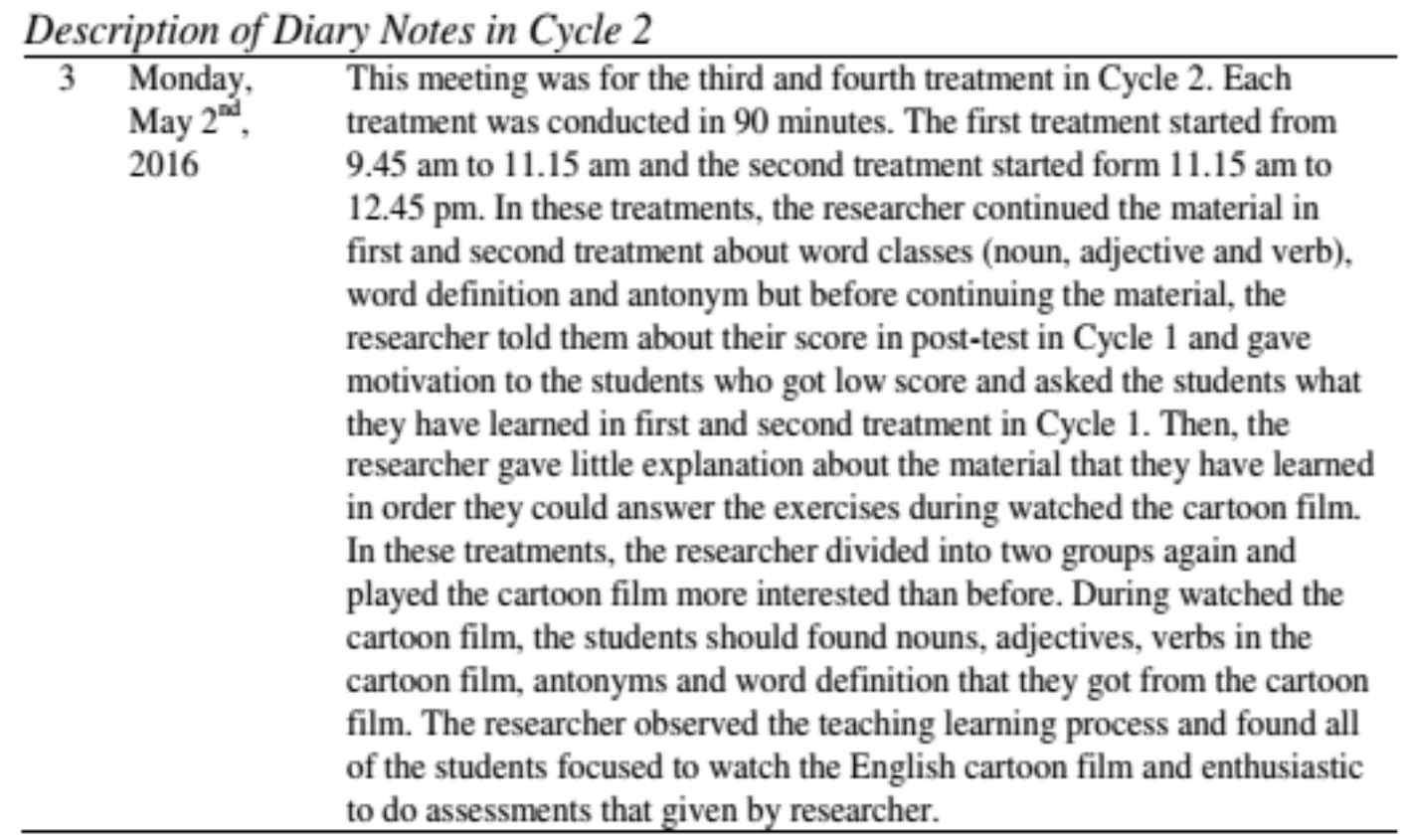

\section{Reflecting}

After implementing the second cycle, the researcher compared the results achieved by the students in Cycle 1 and those in Cycle 2. There were some improvements in the first and second cycles. In Cycle 2, the learning process became more effective than that before. The class was also well managed. The students were more enthusiastic and became more active. It was likely because they were interested and felt comfort with the cartoon film watching. It was proved by the findings that 22 students (or 95.66\%) reached the minimum achievement criteria. The next point was that the students' progress in determining details information they found from the cartoon film made them enjoy and felt not under pressured in doing the exercises. The cartoon films stimulated them to relax when learning the vocabularies. The students' condition during this phase implied that watching English cartoon films benefitted to improve and develop the students' vocabulary mastery. The development could be seen in Figure 1. 


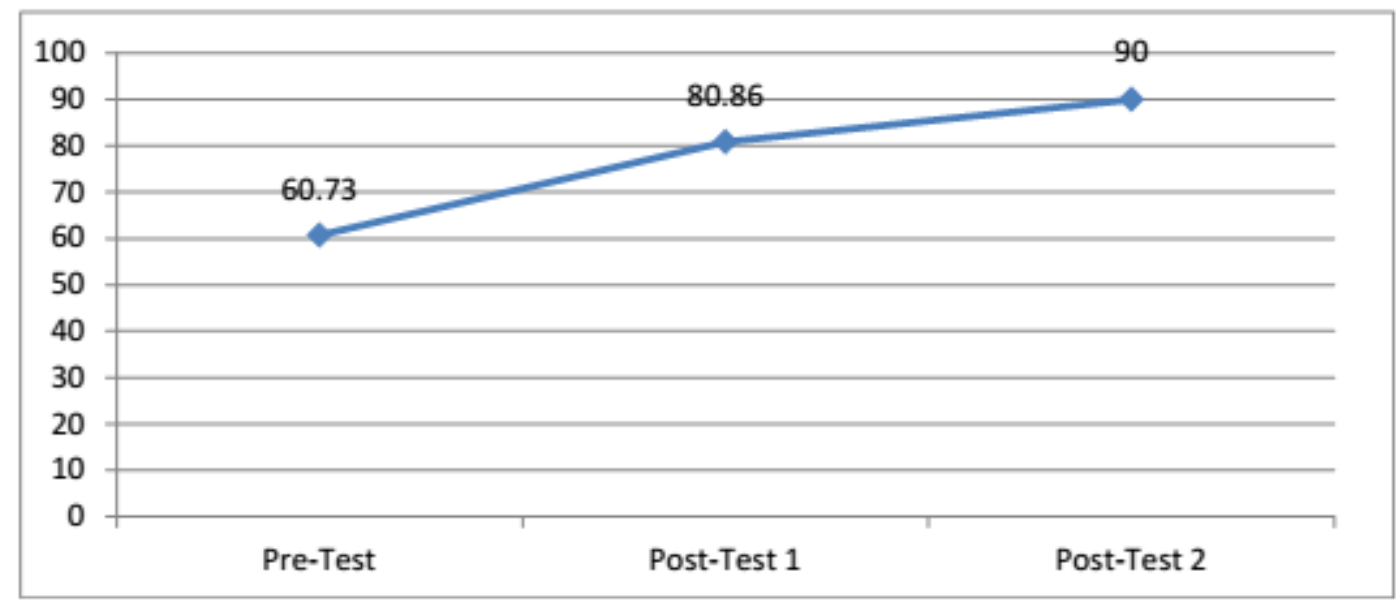

Figure 1. Mean of Pre-Test, Post-Test 1, and Post-Test 2

In Figure 1. it is clearly displayed that the mean score of the post-test in Cycle 1 was 80.86 points and in Cycle 2 was 90.00 points. Based on this fact, it could be pointed out that the students' vocabulary mastery was about 60.73 points. The result of the posttest in each cycle obviously shows that there was improvement concerning the students' vocabulary. In Cycle 2, the researcher also administered a questionnaire to the students as a non-test to collect the qualitative data for this research. The detail of the students' questionnaire was presented as follows:

Table 11

\section{The Analysis Result of Questionnaire}

\begin{tabular}{|c|c|c|c|c|c|c|c|c|c|c|c|}
\hline \multirow{3}{*}{$\begin{array}{l}\mathrm{N} \\
\mathrm{o}\end{array}$} & \multirow{3}{*}{ Questionnaire Items } & \multirow{3}{*}{$\begin{array}{c}\text { Students' } \\
\text { Response } \\
\text { SD } \\
\text { F } \\
\end{array}$} & & & & & & & & & \multirow[b]{3}{*}{$\%$} \\
\hline & & & \multicolumn{2}{|l|}{ D } & \multicolumn{2}{|c|}{$\mathbf{N}$} & \multicolumn{2}{|c|}{$\mathbf{A}$} & \multicolumn{2}{|c|}{$\mathbf{S A}$} & \\
\hline & & & $\%$ & $\mathbf{F}$ & $\%$ & $\mathbf{F}$ & $\%$ & $\mathbf{F}$ & $\%$ & $\mathbf{F}$ & \\
\hline 1 & Suka film kartunberbahasaInggris & 0 & 0 & 0 & 0 & 2 & 8.69 & $\begin{array}{l}1 \\
1\end{array}$ & 47.84 & 10 & 43.47 \\
\hline 2 & $\begin{array}{l}\text { Dapatmenghafalkosakatabahasainggris } \\
\text { melalui film kartunberbahasaInggris }\end{array}$ & 1 & 4.34 & 1 & 4.34 & 6 & 26.08 & $\begin{array}{l}1 \\
3\end{array}$ & 56.52 & 2 & 8.69 \\
\hline 3 & $\begin{array}{l}\text { SukabelajarkosakatabahasaInggrismela } \\
\text { luimenonton film } \\
\text { kartunberbahasaInggris }\end{array}$ & 1 & 4.34 & 0 & 0 & 4 & 17.39 & $\begin{array}{l}1 \\
3\end{array}$ & 56.52 & 5 & 21.73 \\
\hline 4 & $\begin{array}{l}\text { Dapatmemelikibanyakkosakatamelalui } \\
\text { film kartun }\end{array}$ & 0 & 0 & 1 & 4.34 & 0 & 0 & $\begin{array}{l}1 \\
1\end{array}$ & 47.84 & 11 & 47.84 \\
\hline 5 & Senangdenganpenjelasan guru & 0 & 0 & 2 & 8.69 & 3 & 13.04 & $\begin{array}{l}1 \\
3\end{array}$ & 56.52 & 5 & 21.73 \\
\hline 6 & $\begin{array}{l}\text { DapatmengetahuiartikosakatabahasaIn } \\
\text { ggrismelalui film kartunbahasaInggris }\end{array}$ & 0 & 0 & 0 & 0 & 5 & 21.73 & $\begin{array}{l}1 \\
3\end{array}$ & 56.52 & 5 & 21.73 \\
\hline 7 & Sangat menarikmenemukankosakata & 0 & 0 & 1 & 4.34 & 2 & 8.69 & $\begin{array}{l}1 \\
1\end{array}$ & 47.84 & 9 & 39.13 \\
\hline 8 & $\begin{array}{l}\text { Film } \\
\text { kartunberbahasaInggrismembuatfokust } \\
\text { erhadap proses belajarmengajar }\end{array}$ & 0 & 0 & 0 & 0 & 5 & $\begin{array}{c}21.7 \\
3\end{array}$ & $\begin{array}{l}1 \\
2\end{array}$ & 52.17 & 6 & 26.08 \\
\hline 9 & Tugasdari guru & 1 & 4.3 & 0 & 0 & 2 & 8.69 & 1 & 69.5 & 4 & 17.3 \\
\hline
\end{tabular}


Table 11 shows that the students gave good responds related to the technique applied by the researcher during the learning process.

\section{Discussion}

Based on the identification of problem in this research, the mastery of English vocabulary of the eighth graders at SMP BHAKTI Jakarta was relatively less. It was shown through the pre-test scores data indicating the mean scores(60.73 points). Based on the initial observation result, the researcher identified most students did not understand the vocabulary well, especially the word classes (verb, noun, and adjective), antonyms, and word definitions. It can be evidenced through the pre-test scores indicating that 14 students $(60.87 \%)$ did not pass the minimum achievement criteria; 9 students $(39.13 \%)$ did. Compared with the result in pre-test in Cycle 1, 19 students $(82.60 \%)$ passed the minimum achievement criteria (80.86 points). However, although some students' scores improved, the students' attitudes or behaviors during the learning process were still low. This was revealed based on the findings in the diary notes. It showed that students were making conversation one another, and the English cartoon films were not interested. However, at the end of Cycle 222 students (95.66\%) reached higher than the minimum achievement criteria (90.00 points). This finding was in parallel with the notes in the diary. It shows the changing of attitude of the students' interest in watching the cartoon film and more engagement in learning process in the classroom. The improvement of vocabulary mastery using cartoon film as a teaching technique in this research likely revealed around $48.69 \%$ points as shown in Chart 1.

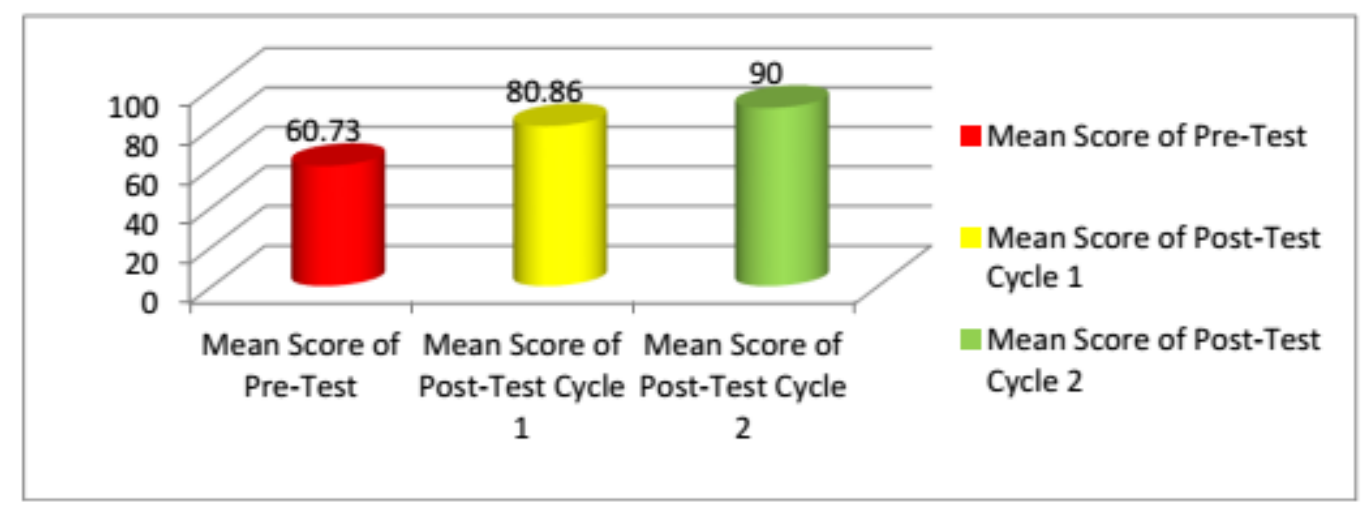

Figure 2. Mean score pre-test, post-test Cycle 1 and post-test Cycle 2 
The analysis results of the qualitative data using questionnaire, observation, and diary notes were considered as additional supporting data. The observation results in Cycle 1 shows that in initial phase some students were not interested to watch the cartoon films; still talk with others, did not work on the exercises; inactive in the classroom. However, in Cycle 2, the students were noted very interested to watch the cartoon film and did the exercises suggested well. Besides, all of the students became active in the classroom during the learning process. The last data supporting the qualitative data was questionnaire. The questionnaire analysis results shows good responses on the vocabulary teaching by watching English cartoon films. Most of them agreed that learning vocabulary through watching English cartoon films was a good strategy or technique in improving English vocabulary mastery.

\section{Conclusion and Suggestions}

Based on the findings, observations, and data analysis carried out in this research, it can be concluded that the implementation of watching English cartoon films in the eighth grade classroom at SMP BHAKTI Jakarta could develop students' vocabulary. It can be seen from the students' result in the pre-test, post-test scores in Cycle 1 and Cycle 2. Watching English cartoon film evidently can make students focused and active during the learning process as revealed in the diary notes and questionnaire analysis results.

Based on the results of research and conclusion previously described, the researcher suggested teachers: (1) to use English cartoon film as an alternative to teaching English, especially vocabulary; (2) to teach not merely depended on the English textbooks, but repare the materials and plan the lessons as well as possible, and to be serious to make the class more active during learning process;(3) to review the topics the students have learnt in the last sessions to help the them remember the previously given materials. Students are suggested to consult the dictionary if they do not know the meanings of the words they find during the English cartoon film watching.

\section{References}

Dakhi, S. \& Zagoto, N. (2016). Foreign language acquisition of souvenir seller in Bawomataluo village. RETORIKA: Jurnal Ilmu Bahasa, 2 (1), pp. 16-32. doi: $10.22225 / \mathrm{jr} .2 .1 .243 .16-32$ 
Hatch, E., \& Brown, C. (1995). Vocabulary, semantics, and language education. Cambridge, England: Cambridge University Press.

Jumariati. (2010). Improving the vocabulary mastery of EFL students. English Dept of FKIP Unlam. Retrieved from ttps://pbingfkipunlam.wordpress.com/2010/01/01/ improving-thevocabulary-mastery-of-efl-students/

Morris, W. (Ed.). (1979). The American heritage dictionary of the english language. Boston: America: Houghton Mifflin Company.

Mukti, P. A. (2012). Improving students' vocabulary mastery using cartoon films (Undergraduate's thesis, Universitas Sebelas Maret, Surakarta, Indonesia). Retrieved from https://digilib.uns.ac.id/Improving-Students-Vocabulary-MasteryUsing-CartoonFilms-A-Classroom-Action-Research-Conducted- at the-SeventhGrade-in-SMP-Negeri-1-Grogol-Sukoharjo-in-the-Academic-Year-20102011abstrak.pdf

Muttahidah, N. (2011). Improving students' vocabulary through vocabulary card (Undergraduate's thesis, Universitas Islam Negeri, Jakarta, Indonesia). Retrieved from http://repository.uinjkt.ac.id/dspace/bitstream/123456789/5206/1/NEATY \%20MUTTAHIDAH-FITK

Pardede, P. (2016). Action Research in EFL Learning and Teaching. Paper presented in UKI's English Education Department Collegiate Forum held on Friday, December 9,2016

Pardede, P. (2012). Meeting the 21st Century ELT Challenges: Becoming a Professional English Teacher. Paper presented in ELT Conference and JELTA Establishment held by the English Teaching Study program of the Christian University of Indonesia Jakarta at GWS Auditorium UKI Jakarta, September 1, 2012.

Woodford, K., \& Walter, E. (Eds.). (2004). Cambridge essential English dictionary. Cambridge, UK: Cambridge University Press. 